\title{
Biofumigation with species of the Brassicaceae family: a review
}

\author{
Carlos Antônio dos Santos $^{1^{*}}$ (D) Antônio Carlos de Souza Abboud ${ }^{1}$ (D) \\ Margarida Goréte Ferreira do $\operatorname{Carmo}^{1}$ (D)
}

${ }^{1}$ Departamento de Fitotecnia, Instituto de Agronomia, Universidade Federal Rural do Rio de Janeiro (UFRRJ), 23897-000, Seropédica, RJ, Brasil. E-mail: carlosantoniokds@gmail.com. "Corresponding author.

\begin{abstract}
Biofumigation involves the release of volatile biocidal compounds in the soil through the incorporation of certain plants and their residues. Species of the Brassicaceae family are the most widely used plants for biofumigation. These plants contain glucosinolates, which produce compounds, such as isothiocyanates, following enzymatic hydrolysis, with scientifically proven fungicidal effects. The most commonly used brassica species belong to the genera Brassica, Raphanus, Sinapis, and Eruca. In addition to the release of compounds in the soil, complementary mechanisms, such as the supply of organic matter and nutrients, and improvement of the soil structure, also play a role in biofumigation. In the past two decades, several studies on the use of brassica residues in biofumigation have been published, showing promising results in the management of soil pathogens (fungi and oomycetes, nematodes, bacteria, and protozoa), weed seeds, and insects. Usage of new biofumigation compounds has also been validated in recent years, including the development of patented technological products such as liquid formulations and pellets. The objective of this article was to review these new developments, beginning with concepts related to biofumigation, and to discuss the mechanisms of action of compounds involving brassica species and the recommendations on usage. Promising examples of the use of this technique are also presented, further detailing the advances in basic and applied knowledge on the subject.
\end{abstract}

Key words: Brassica spp., soil pathogens, glucosinolates, isothiocyanates, green manure.

Biofumigação com espécies da família Brassicaceae: uma revisão

RESUMO: A biofumigação consiste na liberação de compostos biocidas voláteis no solo a partir da incorporação de determinadas plantas $e$ de seus resíduos. As espécies da familia Brassicaceae são as plantas mais utilizadas na biofumigação. Em sua constituição, possuem os glucosinolatos que, após hidrólise enzimática, produzem compostos como os isotiocianatos com efeito biofungicida comprovado cientificamente. As espécies de brássicas mais utilizadas pertencem aos gêneros Brassica, Raphanus, Sinapis e Eruca. Além da liberação de compostos no solo, mecanismos complementares como o fornecimento de matéria orgânica, nutrientes e melhoria da estrutura do solo, também desempenham papel complementar na biofumigação. Diversos estudos foram publicados nas últimas duas décadas com a utilização de resíduos de brássicas na biofumigação e apresentaram resultados promissores no manejo de patógenos de solo (fungos e oomicetos, nematóides, bactérias e protozoários), sementes de plantas daninhas e insetos. Novas formas de utilização também foram validadas nos últimos anos, inclusive com o desenvolvimento de produtos tecnológicos patenteados como formulações líquidas e pellets. Nesta revisão, objetivamos apresentar estes novos desdobramentos iniciando com os conceitos relacionados à biofumigação. Em seguida, apresentamos os mecanismos de ação e compostos envolvidos; as espécies de brássicas, produtos e recomendações para sua utilização; e exemplos promissores de adoção da técnica a nivel mundial. Pretende-se, dessa forma, detalhar os avanços no conhecimento básico e aplicado do assunto. Palavras-chave: Brassica spp., patógenos de solo, glucosinolatos, isotiocianatos, adubação verde.

\section{INTRODUCTION}

The management of soil-borne phytopathogens is a challenge in agricultural production (DIXON \& TILSTON, 2010; GAMLIEL \& BRUGGEN, 2016; LOBO JÚNIOR et al., 2018; DUTTA et al., 2019). Under intensive conventional cultivation systems, volatile chemical compounds of nonspecific action are used frequently in a practice known as soil fumigation (LADHALAKSHMI et al., 2015; LEITE \& LOPES, 2018). Methyl bromide
$\left(\mathrm{CH}_{3} \mathrm{Br}\right)$ is a classic example of a product used for this purpose and, until it was prohibited, around three-quarters of its consumption worldwide was associated with soil fumigation for cultivation of vegetable species (EPSTEIN, 2014). Its prohibition led to limitations in some production sectors, such as vegetables, flowers, and seedlings, and a race began in the search for $\mathrm{CH}_{3} \mathrm{Br}$ substitutes (BAKER et al., 1996; EPSTEIN, 2014; PRASAD et al., 2015). These substitutes included metam sodium $\left(\mathrm{C}_{2} \mathrm{H}_{4} \mathrm{NNaS}_{2}\right)$ and dazomet $\left(\mathrm{C}_{5} \mathrm{H}_{10} \mathrm{~N}_{2} \mathrm{~S}_{2}\right)$ (AGROFIT, 2020), both 
of which are precursors of the volatile compound methyl isothiocyanate.

However, regardless of the product used, fumigation aims to sterilize the soil, which is incompatible with the philosophy and principles of production systems that value the biological activity of the soil, such as organic or agroecological systems (LADHALAKSHMI et al., 2015; BRUGGEN \& FINCKH, 2016; GAMLIEL \& BRUGGEN, 2016). Since the 1990s, studies have investigated alternative proposals or techniques that may be used to replace fumigation with synthetic chemical compounds (KIRKEGAARD et al., 1993; MATTHIESSEN \& KIRKEGAARD, 2006; KIRKEGAARD, 2009; MORRIS et al., 2020). One of these techniques is biofumigation, which involves the application or incorporation of residues from plant species capable of releasing gases with bioactive or biofumigant action. Biofumigation is effective at controlling phytopathogens that cause disease in plants (fungi, oomycetes, nematodes, and bacteria), insects, and weed seeds (KARAVINA \& MANDUMBU, 2012; LADHALAKSHMI et al., 2015; PRASAD et al., 2015; GUREL et al., 2018; DUTTA et al., 2019).

Plant species from the Brassicaceae family have been widely used and studied for biofumigation due to the presence of compounds, including glucosinolates (GSLs), which, after enzymatic hydrolysis, release bioactive gases such as isothiocyanates (GIMSING \& KIRKEGAARD, 2009; NTALLI \& CARBONI, 2017). Brassica or cruciferous plants, a generic name given to species of the Brassicaceae family, are widely consumed by humans and animals, and used for the production of edible and industrial oils (RAHMAN et al., 2018; UGRENOVIĆ et al., 2019). Generally, these plants grow quickly and produce large amounts of biomass. They also provide good soil coverage and are highly efficient at absorbing nutrients (UGRENOVIĆ et al., 2019). Among the Brassicaceae family, species of the genera Brassica, Raphanus, Sinapis, and Eruca are the most commonly used for biofumigation (MATTHIESSEN \& KIRKEGAARD, 2006; CLARKSON et al., 2015; HANSCHEN \& WINKELMANN, 2020; MORRIS et al., 2020).

The technique can be summarized with a sequence of events, beginning with the cultivation of brassica, followed by cutting and fragmentation, incorporation of biomass into the soil, and the addition of water. This process results in the release of bioactive substances, nutrient cycling, increased levels of organic matter in the soil; and consequently, improved physical, chemical, and biological properties (KIRKEGAARD, 2009; CLARKSON et al., 2015). Substantial technological advances have already been achieved in terms of tests and validation, and commercial products based on the cake obtained from pressing brassica seeds are available for oil extraction, liquid formulations, pellets, leaf extracts, and brassica-based oils (LORD et al., 2011; NICOLA et al., 2013; CURTO et al., 2016; WEI et al., 2016; SERRANO-PÉREZ et al., 2017; RONCATO et al., 2018; RUBAYET et al., 2018; PONTES et al., 2019). To date, species of the Brassicaceae family have been tested and used in various countries such as Italy, India, Australia, China, the United Kingdom, Spain, the United States, Argentina, South Africa, Germany, Switzerland (MATTHIESSEN \& KIRKEGAARD, 2006; KIRKEGAARD, 2009; DONALD et al., 2010; PERNIOLA et al., 2012; LAZZERI et al., 2013; MICHEL, 2014; LADHALAKSHMI et al., 2015; WEI et al., 2016; PAN et al., 2017; RÍOS et al., 2017; DANEEL et al., 2018; DUTTA et al., 2019; JIN et al., 2019; CAMPANELLA et al., 2020; HANSCHEN \& WINKELMANN，2020; MORRIS et al., 2020), and Brazil (OLIVEIRA et al., 2011; BARROS et al., 2014; RONCATO et al., 2018). Results obtained around the world have been promising. A meta-analysis including information from 934 biofumigation tests with brassica residues, reported a decreased incidence of diseases and an increase of around $30 \%$ in the productivity of different crops (MORRIS et al., 2020).

Studies on the use of Brassicaceae family plants in biofumigation have advanced in recent decades. This literature review was conducted to collate this information and encourage research and the use of these plants in biofumigation. This review was organized into the following six sections: (1) biofumigation concepts, benefits, and mechanisms of action; (2) main volatile compounds released in the soil following decomposition of residues of Brassicaceae family species involved in the suppression of phytopathogens, insects, and weed species; 3) main brassica species used in biofumigation, their forms of use, and management; 4) main controlled agents and examples of successful and promising experiences; 5) limitations of the technique and current knowledge gaps; 6) non-brassica species and organic residues with similar potential and future prospects.

\section{Biofumigation - definition, benefits, and mechanisms of action}

The term biofumigation was initially proposed to describe a disease control technique that incorporated plants or plant residues into the 
soil to release volatile biocidal compounds during their decomposition (KIRKEGAARD et al., 1993; TSROR et al. 2007; LADHALAKSHMI et al., 2015; PRASAD et al., 2015; HANSCHEN \& WINKELMANN, 2020). This term was originally proposed by J. A. Kirkegaard to describe the process of cultivation, fragmentation, and incorporation of brassica residues (generic name given to species belonging to the Brassicaceae family) with the aim of releasing volatile compounds by the hydrolysis of GSLs present in the tissues of these plants (KIRKEGAARD et al., 1993). Isothiocyanates (ITCs) are among the biologically active products obtained from GSL hydrolysis (GIMSING \& KIRKEGAARD, 2009; KIRKEGAARD, 2009; CLARKSON et al., 2015; MAWAR \& LODHA, 2015; PRASAD et al., 2015). Notably, the volatile compound (methyl isothiocyanate) released by the synthetic fumigants (metam sodium and dazomet) currently sold in Brazil is also an ITC (AGROFIT, 2020).

The term biofumigation integrates a broader phenomenon by involving a series of allelopathic effects that have been empirically observed in brassica for centuries (PRASAD et al., 2015). Currently, a more detailed approach to biofumigation research has demonstrated its positive effects on disease control, thereby improving our understanding of the processes and mechanisms involved, and its practical application (DIXON \& TILSTON, 2010; LAZZERI et al., 2013; CURTO et al., 2016; WEI et al., 2016; MORALESRODRÍGUEZ et al., 2018; DUTTA et al., 2019; JIN et al., 2019; CAMPANELLA et al., 2020; HANSCHEN \& WINKELMANN, 2020; MORRIS et al., 2020). This concept has been expanded and popularized to cover the use of a series of organic vegetable materials and animal production residues (GIMSING \& KIRKEGAARD, 2009; KIRKEGAARD, 2009, PRASAD et al., 2015; KUMAR et al., 2018; DUTTA et al., 2019). Therefore, the concept of biofumigation has been extended to include the aerobic disinfestation of soil by the addition of residues or organic matter, resulting in the release of volatile compounds during decomposition that exert toxicity on undesirable soil organisms (MATTHIESSEN \& KIRKEGAARD, 2006; BRUGGEN \& FINCKH, 2016; GAMLIEL \& BRUGGEN, 2016).

Biofumigation is different from another similar technique known as anaerobic biodesinfestation or anaerobic soil disinfestation. In this case, easily decomposed organic materials are incorporated in the soil in high amounts to stimulate rapid microbial growth. This leads to oxygen depletion due to increased microbial respiration (BRUGGEN
\& FINCKH, 2016; GAMLIEL \& BRUGGEN, 2016; WEI et al., 2016) and the release of toxic compounds and gases from the decomposition of organic matter (LARREGLA et al., 2015). Different types of residue can be used in this process, including brassica (ROSSKOPF et al., 2015). Despite the consensus among most experts and researchers, there are some disagreements about these terminologies and the differences between the two methods, which can lead to misinterpretation.

Aerobic biofumigation can be combined with other techniques, such as soil solarization (LADHALAKSHMI et al., 2015; GAMLIEL \& BRUGGEN, 2016), in which the soil temperature is increased by utilizing the incident solar energy on previously moistened soil covered with transparent polyethylene film (GAMLIEL \& KATAN, 2009). In this case, some researchers prefer to name the combination of these two techniques as 'soil biosolarization' (ROS et al., 2008; VILLALOBOS et al., 2013). This combination enhances their effects, especially in tropical regions where solar radiation is abundant (ROS et al., 2008; BARRAU et al., 2009; VILLALOBOS et al., 2013; GAMLIEL \& BRUGGEN, 2016; ROS et al., 2016).

Biofumigation with the incorporation of brassica residues has other effects in addition to the release of ITCs (MATTHIESSEN \& KIRKEGAARD, 2006; GIMSING \& KIRKEGAARD, 2009; HANSCHEN \& WINKELMANN, 2020), which may enhance the suppression of soilborne phytopathogens (CLARKSON et al., 2015). These effects include increased organic matter content in the soil, with consequent improvements in physical properties and water retention, improved soil fertility due to nutrient cycling and supply, and improved microbial activity (CLARKSON et al., 2015; PRASAD et al., 2015; NTALLI \& CARBONI, 2017). However, a full understanding of this multiplicity of effects on disease suppression remains to be elucidated (CLARKSON et al., 2015).

The efficiency of biofumigation in disease control varies according to the phytopathogen and its sensitivity to the ITCs released during GSL hydrolysis (FAN et al., 2008; MAWAR \& LODHA, 2015). For example, Pythium species have been reported to be least sensitive to these compounds (MAWAR \& LODHA, 2015). Efficiency can also vary according to the life cycle phase of the pathogen and is higher during the active phases, such as fungal mycelia, and lower in survival structures (KUMAR et al., 2018). However, effects on survival structures, especially on Verticillium spp., have also been reported (DIXON \& 
TILSTON, 2010; NEUBAUER et al., 2014; MAWAR \& LODHA, 2015).

\section{Glucosinolates and isothiocyanates}

Glucosinolates (GSLs) are secondary metabolites of some plants compounds containing sulfur and nitrogen (KIRKEGAARD, 2009; LADHALAKSHMI et al., 2015), especially those of the Brassicaceae, Capparidaceae, Tropaeolaceae, Moringaceae, and Amaryllidaceae families (KARAVINA \& MANDUMBU, 2012; LADHALAKSHMI et al., 2015). More than 200 GSLs are reported to occur in about 3,500 plant species of the Brassicaceae family (DUTTA et al., 2019). These compounds can be divided into three groups according to the type of side-chain in their molecules: aromatic, aliphatic, or indole, the hydrolysis of which result in products with different biological activities (ROSA et al., 1997; KIRKEGAARD, 2009; GIMSING \& KIRKEGAARD, 2009).

Plants containing GSLs also produce a hydrolytic enzyme (thioglucosidase hydrolase), commonly known as myrosinase. In intact tissues, there is a physical separation between GSLs and hydrolytic enzymes (ROSA et al., 1997; GIMSING \& KIRKEGAARD, 2009; LADHALAKSHMI et al., 2015; NTALLI \& CARBONI, 2017; HANSCHEN \& WINKELMANN, 2020). However, with tissue maceration or degradation due to insect attack, mechanical damage, or phytopathogen infection, contact between the enzyme and GSLs is increased. This contact triggers GSL hydrolysis and the consequent release of ITCs, such as organic cyanides and thiocyanates (LADHALAKSHMI et al., 2015). The ITCs released through GSL hydrolysis with aliphatic and aromatic chains (KIRKEGAARD, 2009) have high bioactivity and are often associated with efficient disease control (GIMSING \& KIRKEGAARD, 2009). Other compounds can be released during the decomposition of brassica tissues (GIMSING \& KIRKEGAARD, 2009; HANSCHEN \& WINKELMANN, 2020), such as methyl sulfide, dimethyl sulfide, dimethyl disulfide, carbon disulfide, and methanethiol, which can also improve the efficiency of biofumigation (LORD et al., 2011).

Both the disruption of plant tissues and the presence of water are essential for ITC release (GIMSING \& KIRKEGAARD, 2009; KIRKEGAARD, 2009). Hydrolysis reactions occur in the presence of water, and increased soil moisture can increase the efficiency of ITC generation and release (PRASAD et al., 2015; KUMAR et al., 2018). Notably, the use of dry or dehydrated vegetable tissues does not affect GSL and myrosinase conservation in brassica tissues (MICHEL, 2014).

GLS hydrolysis occurs rapidly, and ITCs and other hydrolysis products generally have a short lifespan in the soil, with a rapid decrease in their concentration within a few days and a mean soil persistence of up to 14 days (KIRKEGAARD, 2009). However, residues with high GSL levels can inhibit the growth of microorganisms for up to two weeks after use (MARSCHNER \& RENGEL, 2010).

Main brassicas and products used, and forms of usage

The brassica species used in biofumigation must possess high GSL levels. However, the procedures of using brassicas can vary according to the species, target organism to be controlled, and context of the production system. Worldwide, the main forms of use included: previous cultivation followed by incorporation as green manure; rotational cultivation; addition and incorporation of fresh or dry vegetable residues (MATTHIESSEN \& KIRKEGAARD, 2006; KIRKEGAARD, 2009; CLARKSON et al., 2015; CAMPANELLA et al., 2020; MORRIS et al., 2020); and addition of industrial residues, such as cakes from seed pressing, for oil extraction (KIRKEGAARD, 2009; CURTO et al., 2016; PAN et al., 2017). Commercial products and formulations registered as Biofence ${ }^{\mathrm{TM}}$ (pellets and liquids), which contain high GSL levels (LAZZERI et al., 2013; NICOLA et al., 2013; WEI et al., 2016; SERRANO-PÉREZ et al., 2017), have also been used and evaluated in Italy, England, and Spain. Likewise, some companies have marketed seeds of certain Brassica juncea ('ISCI 20' and 'ISCI 99') and Eruca sativa ('Nemat') cultivars, as they contain high GSL levels, and are recommended for cultivation and for use as biofumigants (TRIUMPH, 2015). At experimental levels, the use of brassica essential oils (DHINGRA et al., 2013; PONTES et al., 2019) and leaf extracts (LORD et al., 2011; RONCATO et al., 2018; RUBAYET et al., 2018) are also promising (Tables 1, 2, 3, 4, 5 and 6).

The strategy to be used should be chosen considering local conditions, farm planning, and the fragmentation and incorporation methods of the biomass produced, or availability of residues or commercial products in nearby locations, in addition to acquisition and transportation costs (KIRKEGAARD, 2009).

The Brassicaceae family species most used for biofumigation belong to the genera Brassica, Raphanus, Sinapis, and Eruca (Tables 1 to 6). Of these, several mustard species are highlighted, 
Table 1 - Promising experimental results obtained for the control of fungi using biofumigation with plant species of the Brassicaceae family.

\begin{tabular}{|c|c|c|c|c|c|c|}
\hline Biofumigant & Target & Host & Strategy & Test type & Comments & Reference \\
\hline $\begin{array}{l}\text { Brassica } \\
\text { oleracea }\end{array}$ & R. solani & Tomato & $\begin{array}{l}\text { Use of fresh } \\
\text { residues }\end{array}$ & $\begin{array}{c}\text { Bioassay, } \\
\text { greenhouse, } \\
\text { field }\end{array}$ & $\begin{array}{l}\text { Reduced symptoms } \\
\text { and increased yield. }\end{array}$ & $\begin{array}{l}\text { TSROR et al. } \\
(2007)\end{array}$ \\
\hline Various species & $\begin{array}{l}\text { Various } \\
\text { species }\end{array}$ & N/A & Powder & In vitro & $\begin{array}{c}\text { Reduced } \\
\text { Ceratobasidium } \\
\text { fimbriata by } 68.6 \% \\
\text { and } V . \text { dahliae by } \\
68.7 \% \text {. }\end{array}$ & FAN et al. (2008) \\
\hline $\begin{array}{l}\text { Brassica } \\
\text { napus, } B . \\
\text { juncea, } B \text {. } \\
\text { campestris }\end{array}$ & $\begin{array}{l}\text { Sclerotinia } \\
\text { sclerotiorum }\end{array}$ & N/A & $\begin{array}{l}\text { Macerated and } \\
\text { dry tissues }\end{array}$ & In vitro & $\begin{array}{l}\text { Growth reduction } \\
\text { and sclerotia } \\
\text { formation. }\end{array}$ & $\begin{array}{l}\text { OJAGHIAN et al. } \\
\qquad(2012)\end{array}$ \\
\hline N/A & $\begin{array}{l}\text { Sclerotium } \\
\text { rolfsii, } S . \\
\text { sclerotiorum }\end{array}$ & N/A & $\begin{array}{c}\text { Mustard } \\
\text { synthetic } \\
\text { essential oil }\end{array}$ & $\begin{array}{l}\text { In vitro, } \\
\text { field }\end{array}$ & $\begin{array}{l}\text { Delayed sclerotia } \\
\text { germination. }\end{array}$ & $\begin{array}{l}\text { DHINGRA et al. } \\
\text { (2013) }\end{array}$ \\
\hline B. juncea & R. solani & Sugar beet & $\begin{array}{l}\text { Planting and } \\
\text { incorporation }\end{array}$ & Field & $\begin{array}{l}\text { Consistent control } \\
\text { of primary } \\
\text { infection. }\end{array}$ & $\begin{array}{l}\text { MOTISI et al. } \\
\quad(2013)\end{array}$ \\
\hline Various species & V. dahliae & N/A & $\begin{array}{l}\text { Residue } \\
\text { incorporation }\end{array}$ & $\begin{array}{l}\text { In vitro, } \\
\text { field }\end{array}$ & $\begin{array}{c}\text { B. juncea } \\
\text { significantly } \\
\text { reduced the number } \\
\text { of viable } \\
\text { microsclerotia. }\end{array}$ & $\begin{array}{c}\text { NEUBAUER et al. } \\
\text { (2014) }\end{array}$ \\
\hline Various species & $\begin{array}{l}\text { Various } \\
\text { species }\end{array}$ & N/A & $\begin{array}{l}\text { Dry powdered } \\
\text { plants }\end{array}$ & In vitro & $\begin{array}{c}\text { Released volatiles } \\
\text { showed inhibitory } \\
\text { effects. }\end{array}$ & $\begin{array}{l}\text { PRASAD et al. } \\
(2016)\end{array}$ \\
\hline Various species & $\begin{array}{c}S . \\
\text { sclerotiorum }\end{array}$ & N/A & $\begin{array}{l}\text { Dry and } \\
\text { ground } \\
\text { residues }\end{array}$ & In vitro & $\begin{array}{c}\text { Effect on mycelial } \\
\text { growth and } \\
\text { germination. }\end{array}$ & $\begin{array}{c}\text { WARMINGTON \& } \\
\text { CLARKSON } \\
(2016)\end{array}$ \\
\hline B. carinata & V. dahliae & N/A & $\begin{array}{c}\text { Pellets (DSM), } \\
\text { liquid } \\
\text { formulation }\end{array}$ & $\begin{array}{l}\text { In vitro, } \\
\text { field }\end{array}$ & $\begin{array}{l}67 \% \text { efficiency } \\
\text { using the liquid } \\
\text { formulation. }\end{array}$ & WEI et al. (2016) \\
\hline B. juncea & $\begin{array}{c}\text { Sclerotinia } \\
\text { homoeocarpa }\end{array}$ & Grass & (DSM) & $\begin{array}{l}\text { In vitro, } \\
\text { field }\end{array}$ & $\begin{array}{l}\text { Reduced mycelial } \\
\text { growth and } \\
\text { incidence. }\end{array}$ & PAN et al. (2017) \\
\hline $\begin{array}{l}\text { B. nigra, } B . \\
\text { oleracea }\end{array}$ & R. solani & Potato & Leaf extract & $\begin{array}{l}\text { In vitro, } \\
\text { field }\end{array}$ & $\begin{array}{l}\text { B. nigra was the } \\
\text { most effective at } \\
\text { inhibiting growth. }\end{array}$ & $\begin{array}{l}\text { RUBAYET et al. } \\
(2018)\end{array}$ \\
\hline
\end{tabular}

N/A - Not applicable. DSM - defatted seed meals.

including Brassica juncea, B. carinata, B. nigra, B. campestris, and Sinapsis alba; radish (Raphanus sativus); arugula (Eruca sativa) (OJAGHIAN et al., 2012; CLARKSON et al., 2015; HANSCHEN \& WINKELMANN, 2020; MORRIS et al., 2020); and Brassica oleracea, mainly cabbage (B. oleracea var. capitata) (MATTHIESSEN \& KIRKEGAARD, 2006; TSROR et al., 2007; VILLALOBOS et al., 2013; BANDYOPADHYAY \& KHALKO, 2016). These species control several target organisms; although, the level of suppression and sensitivity can also vary (KIRKEGAARD \& MATTHIESSEN, 2004; FAN et al., 2008; CAMPANELLA et al., 2020).
Some important aspects must be considered when the previous brassica cultivation is used as green manure, or is included in a crop rotation program, such as species versus climatic conditions, time of year, and susceptibility to target organism (KIRKEGAARD, 2009; DONALD et al., 2010; LU et al., 2010; LAZZERI et al., 2013; KRASNOW \& HAUSBECK, 2015). Species and cultivars with good climatic adaptation to local conditions, rusticity, high biomass yield, and that non-host the pathogen or pest to be controlled should be prioritized.

Aspects that may improve the efficiency of the technique must be considered when biomass 
Table 2 - Promising experimental results obtained in the control of Fusarium spp. using biofumigation with plant species of the Brassicaceae family.

\begin{tabular}{|c|c|c|c|c|c|c|}
\hline Biofumigant & Target & Host & Strategy & Test type & Comments & Reference \\
\hline B. oleracea & $\begin{array}{l}\text { Fusarium } \\
\text { oxysporum }\end{array}$ & N/A & $\begin{array}{l}\text { Crushed } \\
\text { residues }\end{array}$ & In vitro & $\begin{array}{l}\text { Reduced the } \\
\text { population of } F \text {. } \\
\text { oxysporum. }\end{array}$ & $\begin{array}{l}\text { IRIARTE et al. } \\
\qquad(2011)\end{array}$ \\
\hline $\begin{array}{l}\text { B. juncea, } S . \\
\text { alba }\end{array}$ & $\begin{array}{c}F . \\
\text { graminearum }\end{array}$ & N/A & $\begin{array}{l}\text { Crushed } \\
\text { residues }\end{array}$ & In vitro & $\begin{array}{l}\text { Suppressed the } \\
\text { growth of } F \text {. } \\
\text { graminearum. }\end{array}$ & $\begin{array}{l}\text { PERNIOLA et al. } \\
\text { (2012) }\end{array}$ \\
\hline B. juncea & Fusarium sp. & $\begin{array}{l}\text { Bitter } \\
\text { melon, } \\
\text { calabash }\end{array}$ & $\begin{array}{l}\text { Macerated } \\
\text { leaves }\end{array}$ & Bioassay & $\begin{array}{l}\text { Reduced mycelial } \\
\text { growth and } \\
\text { incidence. }\end{array}$ & $\begin{array}{c}\text { RELEVANTE \& } \\
\text { CUMAGUN } \\
(2013)\end{array}$ \\
\hline B. juncea & $\begin{array}{c}F . \\
\text { graminearum }\end{array}$ & N/A & $\begin{array}{l}\text { Crushed } \\
\text { residues }\end{array}$ & In vitro & $\begin{array}{l}\text { Biofumigation } \\
\text { combined with } \\
\text { Trichoderma spp. } \\
\text { had a synergistic } \\
\text { effect against the } \\
\text { pathogen. }\end{array}$ & $\begin{array}{l}\text { PERNIOLA et al. } \\
(2014)\end{array}$ \\
\hline B. carinata & F. circinatum & Pine & Pellets (DSM) & Bioassay & $\begin{array}{l}\text { Inoculum control } \\
\text { and reduced seed } \\
\text { mortality. }\end{array}$ & $\begin{array}{l}\text { MORALES- } \\
\text { RODRÍGUEZ et } \\
\text { al. (2018) }\end{array}$ \\
\hline $\begin{array}{l}\text { B. juncea, } \\
\text { Diplotaxis } \\
\text { tenuifolia }\end{array}$ & $\begin{array}{l}\text { F. oxysporum } \\
\text { f. sp. } \\
\text { cucumerinum }\end{array}$ & Cucumber & $\begin{array}{l}\text { Planting and } \\
\text { incorporation }\end{array}$ & Greenhouse & $\begin{array}{l}\text { Suppressed } \\
\text { Fusarium wilt. }\end{array}$ & JIN et al. (2019) \\
\hline B. carinata & Fusarium spp. & Wheat & $\begin{array}{l}\text { Planting and } \\
\text { incorporation }\end{array}$ & Field & $\begin{array}{c}\text { Reduced incidence } \\
\text { and severity; } \\
\text { increased yield. }\end{array}$ & $\begin{array}{c}\text { CAMPANELLA et } \\
\text { al. }(2020)\end{array}$ \\
\hline
\end{tabular}

N/A - Not applicable. DSM - defatted seed meals.

is incorporated into the soil. These aspects included: the species to be incorporated and their cycle phase, fragmentation and incorporation method, soil moisture, and method of waterproofing of the soil surface. The accumulation of GSLs in brassica depends on the developmental stage of each species. However, in general, higher levels are observed during vegetative growth with decreasing levels observed after flowering (KIRKEGAARD, 2009). Thus, in most cases, the pre-flowering phase is the most suitable for cutting and incorporation (DONALD et al., 2010; KARAVINA \& MANDUMBU, 2012; DUTTA et al., 2019; CAMPANELLA et al., 2020). Biomass cutting and fragmentation procedures can also interfere with the efficiency of the technique; the more uneven and larger the fragments, the more heterogeneous the distribution and release of volatile compounds. This decreases biofumigation efficiency (KARAVINA \& MANDUMBU, 2012; MAWAR \& LODHA, 2015). Vegetal materials cultivated in the area or brought from other places should be wellfragmented and immediately incorporated into the soil, at a depth of $15-20 \mathrm{~cm}$, using a rotary hoe or disk harrow (KUMAR et al., 2018). Another essential factor is soil humidity, since water is essential for GSL hydrolysis following cell rupture; therefore, the soil must be irrigated up to field capacity immediately after the incorporation of residues to optimize this reaction (MATTHIESSEN \& KIRKEGAARD, 2006; GIMSING \& KIRKEGAARD, 2009; KIRKEGAARD, 2009; DONALD et al., 2010; KUMAR et al., 2018; DUTTA et al., 2019). Additionally, as many of the products released during GSL hydrolysis are volatile, losses can be reduced if the soil is covered with transparent plastic film after incorporation (CLARKSON et al., 2015; ROS et al., 2016; DUTTA et al., 2019), or if the surface is sealed with a roller and/or irrigation (DONALD et al., 2010). According to Kirkegaard (2009), the use of plastic is not mandatory, despite increasing the efficiency of volatile compound retention (KIRKEGAARD, 2009). The incorporation of residues into the soil can also coincide with standard plastic mulching, which is commonly used for some crops, including strawberry-growing systems (KIRKEGAARD, 2009; BRUGGEN et al., 2016).

Signs of phytotoxicity have been reported in crops introduced soon after the incorporation 
Table 3 - Promising experimental results obtained in the control of oomycetes using biofumigation with plant species of the Brassicaceae family.

\begin{tabular}{|c|c|c|c|c|c|c|}
\hline Biofumigant & Target & Host & Strategy & Test type & Comments & Reference \\
\hline $\begin{array}{l}\text { Brassica juncea, } \\
\text { Iberis amara }\end{array}$ & Pythium spp. & N/A & $\begin{array}{c}\text { Dehydrated } \\
\text { plants (pellets) }\end{array}$ & In vitro & $\begin{array}{l}\text { After adding water, the } \\
\text { dried plants showed } \\
\text { fungitoxic activity } \\
\text { against Pythium spp. }\end{array}$ & $\begin{array}{l}\text { LAZZERI et al. } \\
\qquad(2004)\end{array}$ \\
\hline $\begin{array}{l}\text { Brassica } \\
\text { carinata }\end{array}$ & $\begin{array}{l}\text { Phytophthora } \\
\text { cactorum }\end{array}$ & Strawberry & $\begin{array}{c}\text { Residue } \\
\text { incorporation }\end{array}$ & Field & $\begin{array}{c}\text { Biofumigation, } \\
\text { combined with } \\
\text { solarization reduced the } \\
\text { occurrence of the } \\
\text { pathogen and increased } \\
\text { yield. }\end{array}$ & $\begin{array}{l}\text { BARRAU et al. } \\
\text { (2009) }\end{array}$ \\
\hline B. oleracea & $\begin{array}{l}\text { Various } \\
\text { species }\end{array}$ & $\begin{array}{l}\text { Sweet } \\
\text { pepper }\end{array}$ & $\begin{array}{c}\text { Fresh residues } \\
+ \text { solarization }\end{array}$ & Field & $\begin{array}{c}\text { Reduction of plants with } \\
\text { symptoms and increased } \\
\text { yield. }\end{array}$ & $\begin{array}{l}\text { VILLALOBOS } \\
\text { et al. (2013) }\end{array}$ \\
\hline B. napus & $\begin{array}{l}\text { Phytophthora } \\
\text { capsici }\end{array}$ & Pepper & Ground seeds & Field & $\begin{array}{l}\text { Reduced incidence } \\
\text { through changes in the } \\
\text { structure of the soil } \\
\text { microbial community. }\end{array}$ & $\begin{array}{l}\text { WANG et al. } \\
\qquad(2014 a)\end{array}$ \\
\hline B. napus & P. capsici & Pepper & Ground seeds & Bioassay & $\begin{array}{l}\text { Reduced disease and } \\
\text { increased bacterial } \\
\text { diversity in the soil. }\end{array}$ & $\begin{array}{l}\text { WANG et al. } \\
\qquad(2014 \mathrm{~b})\end{array}$ \\
\hline B. carinata & P. cinnamomi & $\begin{array}{l}\text { Quercus } \\
\text { cerris }\end{array}$ & Pellets (DSM) & $\begin{array}{l}\text { In vitro, } \\
\text { bioassay }\end{array}$ & $\begin{array}{l}\text { Inhibited mycelial } \\
\text { growth and germination } \\
\text { of chlamydospores and } \\
\text { zoospores, and reduced } \\
\text { inoculum potential. }\end{array}$ & $\begin{array}{l}\text { MORALES- } \\
\text { RODRÍGUEZ et } \\
\text { al. (2016) }\end{array}$ \\
\hline $\begin{array}{l}\text { B. carinata, } B . \\
\text { juncea, B. napus }\end{array}$ & P. cinnamomi & $\begin{array}{l}\text { Yellow } \\
\text { lupin }\end{array}$ & Ground seeds & $\begin{array}{l}\text { In vitro, } \\
\text { bioassay }\end{array}$ & $\begin{array}{l}\text { B. carinata and } B \text {. juncea } \\
\text { reduced mycelial growth } \\
\text { and decreased } P \text {. } \\
\text { cinnamomi viability in } \\
\text { the soil. }\end{array}$ & $\begin{array}{l}\text { RÍOS et al. } \\
\quad(2017)\end{array}$ \\
\hline B. carinata & P. nicotianae & N/A & Pellets (DSM) & In vitro & $\begin{array}{c}\text { Reduced chlamydospore } \\
\text { germination. }\end{array}$ & $\begin{array}{l}\text { SERRANO- } \\
\text { PÉREZ et al. } \\
\quad(2017)\end{array}$ \\
\hline
\end{tabular}

N/A - Not applicable. DSM - defatted seed meals.

of brassica; therefore, it is advisable to wait for a minimum of 2 weeks between biofumigation and the planting of subsequent crops to ensure the dissipation of phytotoxic compounds (KIRKEGAARD, 2009; CLARKSON et al., 2015; MAWAR \& LODHA, 2015). When plastic film is used, it can be removed after 3-4 weeks, and the soil should be slightly stirred to allow gases to be exhausted from the soil. The next crop can be planted 24 hours after this procedure (KUMAR et al., 2018).

In addition to fresh biomass, such as green manure, brassicas have been used in different ways for soil biofumigation in commercial production areas (LAZZERI et al., 2013). Examples included the use of residues as the cake resulting from seed pressing for oil extraction (CURTO et al., 2016), liquid formulations (NICOLA et al., 2013), and pellets (WEI et al., 2016; SERRANO-PÉREZ et al., 2017). The cake is an interesting form of use, because the seeds tend to accumulate GSL during ripening; the concentration of these compounds is $8-10$ times higher than that in other parts of the plants (LAZERRI et al., 2013). One example is the use of residues from Abyssinian mustard seed pressing (Brassica carinata) to produce biodiesel and derived products, which are rich in GSLs and can be used in the production of biofumigants (KIRKEGAARD, 2009; LAZZERI et al., 2013; NICOLA et al., 2013; LADHALAKSHMI et al., 2015; CURTO et al., 2016; WEI et al., 2016; SERRANO-PÉREZ et al., 2017). Cakes resulting from brassica seed pressing (defatted seed meal DSM), as well as their derived technological products, 
Table 4 - Promising experimental results obtained in the control of nematodes using biofumigation with plant species of the Brassicaceae family.

\begin{tabular}{|c|c|c|c|c|c|c|}
\hline Biofumigant & Target & Host & Strategy & Test type & Comments & Reference \\
\hline $\begin{array}{l}\text { Raphanus } \\
\text { sativus, } B . \\
\text { juncea, Sinapis } \\
\text { alba }\end{array}$ & $\begin{array}{l}\text { Various } \\
\text { species }\end{array}$ & $\begin{array}{l}\text { Onion, } \\
\text { celery }\end{array}$ & $\begin{array}{l}\text { Planting and } \\
\text { incorporation }\end{array}$ & Field & $\begin{array}{c}\text { Reduced parasitic } \\
\text { nematodes in celery. }\end{array}$ & $\begin{array}{l}\text { WANG et al. } \\
\qquad(2006)\end{array}$ \\
\hline B. carinata & M. chitwoodi & Potato & Pellets (DSM) & Field & $\begin{array}{l}\text { Reduced nematode } \\
\text { damage in the root and } \\
\text { increased yield. }\end{array}$ & $\begin{array}{l}\text { HENDERSON et } \\
\text { al. (2009) }\end{array}$ \\
\hline Various species & $\begin{array}{l}\text { Globodera } \\
\text { pallida }\end{array}$ & N/A & Leaf extract & In vitro & $\begin{array}{l}\text { Presented toxicity to } \\
\text { nematodes and } \\
\text { inhibited the activity of } \\
\text { juveniles. }\end{array}$ & $\begin{array}{l}\text { LORD et al. } \\
\qquad(2011)\end{array}$ \\
\hline B. juncea & M. incognita & Tomato & Various & $\begin{array}{l}\text { In vitro, } \\
\text { greenhouse }\end{array}$ & $\begin{array}{l}\text { Reduced number of } \\
\text { galls, egg mass, and } \\
\text { eggs in tomato plants } \\
\text { by over } 90 \% .\end{array}$ & $\begin{array}{l}\text { OLIVEIRA et al. } \\
\text { (2011) }\end{array}$ \\
\hline B. carinata & M. incognita & Tomato & $\begin{array}{l}\text { Liquid } \\
\text { formulation }\end{array}$ & Bioassay & $\begin{array}{l}\text { Statistically significant } \\
\text { dose-effect correlations } \\
\text { related to } \\
\text { isothiocyanate release. }\end{array}$ & $\begin{array}{l}\text { NICOLA et al. } \\
\qquad(2013)\end{array}$ \\
\hline B. juncea & M. incognita & N/A & Leaf macerates & In vitro & $\begin{array}{l}\text { Macerate and volatile } \\
\text { organic compounds } \\
\text { released have } \\
\text { nematicidal effect. }\end{array}$ & $\begin{array}{l}\text { BARROS et al. } \\
\qquad(2014)\end{array}$ \\
\hline $\begin{array}{l}B . \text { juncea, } R . \\
\text { sativus, Eruca } \\
\text { sativa }\end{array}$ & G. pallida & Potato & $\begin{array}{l}\text { Planting and } \\
\text { incorporation }\end{array}$ & Field & $\begin{array}{c}\text { B. juncea and } R \text {. sativus } \\
\text { showed to be promising } \\
\text { for integrated nematode } \\
\text { management systems in } \\
\text { potatoes. }\end{array}$ & $\begin{array}{l}\text { NGALA et al. } \\
\qquad(2015)\end{array}$ \\
\hline Various species & M. incognita & Tomato & DSM & Greenhouse & $\begin{array}{c}\text { Better results with } \\
\text { Eruca sativa, Barbarea } \\
\text { verna, and Brassica } \\
\text { nigra. }\end{array}$ & $\begin{array}{l}\text { CURTO et al. } \\
\quad(2016)\end{array}$ \\
\hline $\begin{array}{l}\text { R. sativus, } B . \\
\text { juncea, S. alba }\end{array}$ & M. incognita & $\begin{array}{l}\text { Sweet } \\
\text { pepper }\end{array}$ & $\begin{array}{l}\text { Planting, } \\
\text { incorporation } \\
+ \text { solarization }\end{array}$ & Greenhouse & $\begin{array}{l}\text { Biosolarization with } \\
\text { brassicas reduced the } \\
\text { population of juveniles } \\
\text { in the soil. }\end{array}$ & ROS et al. (2016) \\
\hline $\begin{array}{l}R \text {. sativus, } E \text {. } \\
\text { sativa }\end{array}$ & M. arenaria & Tomato & $\begin{array}{l}\text { Planting and } \\
\text { incorporation }\end{array}$ & Greenhouse & $\begin{array}{l}\text { Galls and egg masses } \\
\text { decreased significantly. }\end{array}$ & $\begin{array}{c}\text { AYDINLI \& } \\
\text { MENNAN (2018) }\end{array}$ \\
\hline $\begin{array}{l}\text { E. sativa, } R \text {. } \\
\text { sativus, } B \text {. juncea }\end{array}$ & $\begin{array}{c}\text { M. } \\
\text { incognita, } \\
\text { M. javanica }\end{array}$ & $\begin{array}{l}\text { Tomato, } \\
\text { potato }\end{array}$ & $\begin{array}{l}\text { Planting and } \\
\text { incorporation }\end{array}$ & Greenhouse & $\begin{array}{l}\text { Reduced inoculum } \\
\text { density and increased } \\
\text { yield. }\end{array}$ & $\begin{array}{l}\text { DANEEL et al. } \\
(2018)\end{array}$ \\
\hline $\begin{array}{l}\text { Crambe } \\
\text { abyssinica }\end{array}$ & M. incognita & Tomato & Leaf extract & Greenhouse & $\begin{array}{l}\text { Crambe extract weekly } \\
\text { incorporated into the } \\
\text { soil was promising for } \\
M \text {. incognita } \\
\text { management in tomato. }\end{array}$ & $\begin{array}{l}\text { RONCATO et al. } \\
(2018)\end{array}$ \\
\hline
\end{tabular}

N/A - Not applicable. DSM - defatted seed meals.

can be used for the production of vegetable species both in Brazil and globally. These materials contain high GSL levels and are sources of nitrogen and other nutrients (MATTHIESSEN \& KIRKEGAARD, 2006; LADHALAKSHMI et al., 2015; CURTO et al., 2016; DUTTA et al., 2019; HANSCHEN \& WINKELMANN, 2020).
There are several practical examples and technological Brassica spp. products patented for use as biofumigants to control pathogens (LAZZERI et al., 2013; NICOLA et al., 2013; LADHALAKSHMI et al., 2015). Likewise, it is possible to buy mustard cultivars that are selected and marketed for cultivation to incorporate biomass for soil biofumigation (TRIUMPH, 2015).

Ciência Rural, v.51, n.1, 2021. 
Table 5 - Promising experimental results obtained in the control of phytopathogenic bacteria and protozoa using biofumigation with plant species of the Brassicaceae family.

\begin{tabular}{|c|c|c|c|c|c|c|}
\hline Biofumigant & Target & Host & Strategy & Test type & Comments & Reference \\
\hline \multicolumn{7}{|c|}{ Bacteria } \\
\hline B. oleracea & S. scabies & Potato & $\begin{array}{l}\text { Incorporation } \\
\text { of dry and } \\
\text { ground } \\
\text { residues }\end{array}$ & Field & $\begin{array}{c}\text { Disease } \\
\text { suppression } \\
\text { by } 90 \% .\end{array}$ & $\begin{array}{l}\text { GOUWS \& WEHNER } \\
(2004)\end{array}$ \\
\hline $\begin{array}{l}\text { B. juncea, } R . \\
\text { sativus, } B . \\
\text { oleracea }\end{array}$ & $\begin{array}{c}R . \\
\text { solanacearum }\end{array}$ & Potato & $\begin{array}{c}\text { Residue } \\
\text { incorporation }\end{array}$ & Field & $\begin{array}{l}\text { Significant } \\
\text { suppression } \\
\text { of wilt by up } \\
\text { to } 50 \% .\end{array}$ & KIRKEGAARD (2009) \\
\hline B. oleracea & $\begin{array}{c}R . \\
\text { solanacearum }\end{array}$ & Ginger & $\begin{array}{c}\text { Residue } \\
\text { incorporation }\end{array}$ & Field & $\begin{array}{l}\text { Lowered } \\
\text { incidence of } \\
\text { wilt and } \\
\text { higher crop } \\
\text { yield. }\end{array}$ & $\begin{array}{c}\text { BANDYOPADHYAY \& } \\
\text { KHALKO (2016) }\end{array}$ \\
\hline B. juncea & $\begin{array}{c}R . \\
\text { solanacearum }\end{array}$ & Tomato & $\begin{array}{c}\text { Mustard } \\
\text { essential oil }\end{array}$ & In vitro & $\begin{array}{c}\text { Cell } \\
\text { mortality } \\
\text { and } \\
\text { inhibition of } \\
\text { colony }\end{array}$ & PONTES et al. (2019) \\
\hline \multicolumn{7}{|c|}{ Protozoa } \\
\hline $\begin{array}{l}\text { B. rapa, } B . \\
\text { napus }\end{array}$ & P. brassicae & $\begin{array}{l}\text { Chinese } \\
\text { cabbage }\end{array}$ & $\begin{array}{l}\text { Planting and } \\
\text { incorporation }\end{array}$ & $\begin{array}{l}\text { Greenhouse, } \\
\text { field }\end{array}$ & $\begin{array}{l}\text { Reduced } \\
\text { severity in } \\
\text { roots with } \\
\text { density } \\
\text { greater than } \\
8 \text { plants } \mathrm{m}^{-2} \text {. }\end{array}$ & CHEAH et al. (2001) \\
\hline $\begin{array}{l}\text { B. rapa, } B . \\
\text { napus }\end{array}$ & P. brassicae & Various & $\begin{array}{l}\text { Planting and } \\
\text { incorporation }\end{array}$ & Field & $\begin{array}{l}\text { B. rapa } \\
\text { reduced } \\
\text { severity and } \\
\text { increased } \\
\text { mass in } \\
\text { cauliflower } \\
\text { plants. }\end{array}$ & CHEAH et al. (2006) \\
\hline
\end{tabular}

In general, the principles of disease control using biofumigants based on industrial residues or press cakes for oil extraction are consistent with those using organic fertilizers. However, they are optimized in terms of time and agricultural space, as they do not involve the pre-cultivation of brassica for later incorporation (KIRKEGAARD, 2009). Another technology being development is pellets obtained from plants or parts of the plant rich in GSLs. The in vitro bioactivity of these pellets against Pythium and Rhizoctonia was reported by LAZZERI et al. in 2004. For example, B. carinata seed cake pellets were obtained after pressing for oil extraction. This product is registered in Italy as BioFence ${ }^{\mathrm{TM}}$ (Triumph Italia SPA, Cerealetoscana Group) and has demonstrated satisfactory results in the control of Phytophthora nicotianae (SERRANO-PÉREZ et al., 2017).

The hydrophobic nature of GSL degradation products has enabled the development of liquid formulations based on vegetable oil emulsion in water and residues from $B$. carinata seed oil extraction (LAZZERI et al., 2011; LAZZERI et al., 2013; NICOLA et al., 2013). This formulation was developed for use via drip irrigation, and has demonstrated good results in the control of Meloidogyne incognita and Verticilium dahliae (NICOLA et al., 2013; WEI et al., 2016). According to WEI et al. (2016), depending on the characteristics of this formulation, a liquid version of BioFence ${ }^{\mathrm{TM}}$ may be more efficient at releasing ITCs than the efficiency observed with pellets, as it facilitates the dispersion of the active ingredient through the soil.

Promising results using brassicas in biofumigation Fifty reports published over the last 20 years were selected to systematically analyze the accumulated data on the use of brassicas for 
Table 6 - Promising experimental results obtained in the control of weeds and insects using biofumigation with plant species of the Brassicaceae family.

\begin{tabular}{|c|c|c|c|c|c|c|}
\hline Biofumigant & Target & Host & Strategy & Test type & Comments & Reference \\
\hline & Weed & & & & & \\
\hline B. juncea, S. alba & $\begin{array}{l}\text { Various } \\
\text { species }\end{array}$ & N/A & $\begin{array}{l}\text { Crushed } \\
\text { residues }\end{array}$ & In vitro & $\begin{array}{l}\text { At the evaluated } \\
\text { doses, } B \text {. juncea, } \\
\text { significantly } \\
\text { inhibited weed } \\
\text { germination. }\end{array}$ & PERNIOLA et al. (2016) \\
\hline B. juncea & $\begin{array}{l}\text { Various } \\
\text { species }\end{array}$ & N/A & Powder & Bioassay & $\begin{array}{c}\text { Biofumigation } \\
\text { showed potential to } \\
\text { be included in weed } \\
\text { management } \\
\text { programs. }\end{array}$ & $\begin{array}{l}\text { LEFEBVRE et al. } \\
\qquad(2018)\end{array}$ \\
\hline B. juncea & $\begin{array}{l}\text { Various } \\
\text { species }\end{array}$ & N/A & $\begin{array}{l}\text { Incorporation } \\
\text { of crushed } \\
\text { residues. } \\
\text { Powder }\end{array}$ & $\begin{array}{l}\text { Bioassay, } \\
\text { field }\end{array}$ & $\begin{array}{c}\text { Highly effective } \\
\text { (mortality }>85 \%) \\
\text { against small seeds, } \\
(0 \% \text { to } 20 \% \text { ) against } \\
\text { hard and large seed } \\
\text { species. Propagule } \\
\text { mortality }>90 \% .\end{array}$ & CAUWER et al. (2019) \\
\hline \multirow[t]{2}{*}{ B. juncea } & $\begin{array}{l}\text { Various } \\
\text { species }\end{array}$ & N/A & $\begin{array}{l}\text { Crushed } \\
\text { residues }\end{array}$ & Greenhouse & $\begin{array}{l}\text { Biofumigation with } \\
2.5 \mathrm{~kg} \mathrm{~m}^{-2} \text { was an } \\
\text { alternative tool for } \\
\text { integrated weed } \\
\text { management. }\end{array}$ & PERNIOLA et al. (2019) \\
\hline & Insects & & & & & \\
\hline E. sativa & $\begin{array}{l}\text { Stored } \\
\text { product } \\
\text { pests }\end{array}$ & $\mathrm{N} / \mathrm{A}$ & $\begin{array}{l}\text { ITCs extracted } \\
\text { from seeds }\end{array}$ & Bioassay & $\begin{array}{c}\text { Effects of } \\
\text { isothiocyanates on } \\
\text { adults and larvae of } \\
\text { stored product pests. }\end{array}$ & $\begin{array}{c}\text { SHAAYA \& } \\
\text { KOSTYUKOVSKY } \\
(2010)\end{array}$ \\
\hline $\begin{array}{l}\text { B. carinata; } B . \\
\text { juncea }\end{array}$ & $\begin{array}{l}\text { Agriotes } \\
\text { brevis, } A \text {. } \\
\text { sordidus, } \\
\quad \text { A. } \\
\text { ustulatus }\end{array}$ & $\begin{array}{l}\text { Lettuce, } \\
\text { corn }\end{array}$ & $\begin{array}{l}\text { DSM, chopped } \\
\text { residues }\end{array}$ & $\begin{array}{l}\text { Bioassay, } \\
\text { field }\end{array}$ & $\begin{array}{l}\text { Insecticidal effect } \\
\text { with high larval } \\
\text { mortality and crop } \\
\text { protection. }\end{array}$ & FURLAN et al. (2010) \\
\hline
\end{tabular}

N/A - Not applicable. ITCs - Isothiocyanates. DSM - defatted seed meals.

biofumigation (Tables 1 to 6). Some important results reported in periods prior to this can be found in KIRKEGAARD \& MATTHIESSEN (2004) and MATTHISSEN \& KIRKEGAARD (2006).

The present survey included tests that used brassica species to control fungi (Tables 1 and 2), oomycetes (Table 3), nematodes (Table 4), phytopathogenic bacteria, and protozoa (Table 5); weeds; and insects, including some species that are stored product pests (Table 6). Notably, in this analysis, the pathogen Plasmodiophora brassicae was grouped as a protozoan, considering different publications and recent phylogenetic analyses that included this species in the protist supergroup Rhizaria (BURKI et al., 2010; SCHWELM et al., 2015; BHERING et al., 2020).

Most reports involved the use of biofumigation or tests with species or products obtained from plants of the Brassicaceae family to control diseases in vegetables, such as tomatoes (Solanum lycopersicum), potatoes (S. tuberosum), peppers, and sweet peppers (Capsicum spp.) (GOUWS \& WEHNER, 2004; TSROR et al., 2007; HENDERSON et al., 2009; KIRKEGAARD, 2009; OLIVEIRA et al., 2011; NICOLA et al., 2013; VILLALOBOS et al., 2013; WANG et al., 2014a,b; NGALA et al., 2015; CURTO et al., 2016; ROS et al., 2016; AYDINLI \& MENNAN, 2018; DANEEL et al., 2018; RONCATO et al., 2018; RUBAYET et al., 2018; PONTES et al., 2019; MORRIS et al., 2020). Studies have also reported the use of biofumigation to control diseases in less known species with promising results, such as bitter melon (Momordica charantia) and calabash (Lagenaria siceraria) (RELEVANTE \& CUMAGUN, 2013); ginger (Zingiber officinale) 
(BANDYOPADHYAY \& KHALKO, 2016); oak (Quercus cerris) (MORALES-RODRÍGUEZ et al., 2016); creeping bentgrass (Agrostis stolonifera) (PAN et al., 2017); yellow lupin (Lupinus luteus) (RÍOS et al., 2017); and pine (Pinus radiata) (MORALESRODRÍGUEZ et al., 2018).

There have been positive reports on the suppressive effect of Brassicaceae species in relation to soilborne phytopathogens, such as Rhizoctonia solani, Verticillium dahliae, Sclerotinia sclerotiorum, Sclerotium rolfsii, Fusarium spp., and Phytophthora spp. (Tables 1 to 3 ). The growth of these agents has been reported to decrease in vitro, and the incidence of diseases they cause in the investigated host species has also been reported to decrease (TSROR et al., 2007; BARRAU et al., 2009; OJAGHIAN et al., 2012; PERNIOLA et al., 2012; DHINGRA et al., 2013; NEUBAUER et al., 2014; WANG et al., 2014 a,b; RUBAYET et al., 2018; CAMPANELLA et al., 2020).

The control of a series of phytoparasitic nematodes with biofumigation was reported by NTALLI \& CARBONI (2017) and DUTTA et al. (2019). Most studies have involved the action of brassica residues or derived products on species of the genus Meloidogyne (Table 4) (HENDERSON et al., 2009; OLIVEIRA et al., 2011; NICOLA et al., 2013; BARROS et al., 2014; CURTO et al., 2016; ROS et al., 2016; AYDINLI \& MENNAN, 2018; DANEEL et al., 2018; RONCATO et al., 2018). The use of E. sativa, Barbarea verna, and Brassica nigra DSM (defatted seed meals) reduced the occurrence of $M$. incognita and increased the development of tomato plants (CURTO et al., 2016). Crambe leaf extract (Crambe abyssinica) weekly incorporated into the soil reduced $M$. incognita second stage juveniles (J2) and eggs in tomato roots by up to $61.57 \%$ (RONCATO et al., 2018).

There have been few reports on the use and biofumigation potential of phytobacteria (Table 5 ); although, the technique is commonly associated with changes in bacterial community, structure, and diversity (WANG et al., 2014a,b; JIN et al., 2019; HANSCHEN \& WINKELMANN, 2020). Some promising results have been obtained with the incorporation of dry and ground $B$. oleracea residues to control bacterial wilt (Ralstonia solanacearum) in potatoes, ginger, and tomatoes (KIRKEGAARD, 2009; BANDYOPADHYAY \& KHALKO, 2016; PONTES et al., 2019), and common mange (Streptomyces scabies) in potatoes (GOUWS \& WEHNER, 2004). For common mange, a reduction of up to $90 \%$ in disease intensity was reported (GOUWS \& WEHNER, 2004). The incorporation of cabbage residues reduced the incidence of bacterial wilt ( $R$. solanacearum) and increased yield in ginger (BANDYOPADHYAY \& KHALKO, 2016). The use of mustard essential oil (B. juncea) increased cell mortality and inhibited the growth of $R$. solanacearum colonies in vitro, thereby reducing the incidence of bacterial wilt in tomatoes (PONTES et al., 2019).

In New Zealand, the prior cultivation and incorporation of B. rapa and B. napus residue reduced the severity of clubroot caused by the protozoan Plasmodiophora brassicae in Chinese cabbage (B. rapa), cauliflower (B. oleracea var. botrytis), and broccoli (B. oleracea var. italica), mainly with the use of $B$. rapa. These species positively influenced the yield of the respective crops (CHEAH et al., 2001; 2006). In this case, it is notable that the species used for biofumigation are also pathogen hosts (DIXON \& TILSTON, 2010). Thus, despite the positive reports by some authors, its use requires further analysis.

Biofumigation with brassica residues has also shown promising results in reducing weed seed banks and propagules in the soil (Table 6). The use of $B$. juncea residue $\left(2.5 \mathrm{~kg} \mathrm{~m}^{-2}\right)$ reduced the population of mono and dicotyledonous species, especially Digitaria sanguinalis, Portulaca oleracea, and Taraxacum officinalis (PERNIOLA et al., 2019). Crushed residues of the same species also inhibited the germination of Anoda cristata, Picris echiodes, and $P$. oleracea seeds (PERNIOLA et al., 2016). The incorporation of $B$. juncea crushed residues effectively controlled weeds ( $>85 \%$ mortality of small seeds) and decreased hard and large seed species (0-20\%) (CAUWER et al., 2019).

Fresh $B$. juncea residues and $B$. carinata DSM were evaluated against Agriotes brevis, A. sordidus, and $A$. ustulatus larvae by FURLAN et al. (2010). The B. carinata cake resulted in high larval mortality and prevented the larvae from damaging the crops (FURLAN et al., 2010). SHAAYA \& KOSTYUKOVSKY (2010) evaluated the toxicity of isothiocyanates extracted from $E$. sativa seeds against stored product pests. The authors reported that the use of isothiocyanates significantly increased the mortality of larvae and adults of the insect species evaluated.

\section{Technique limitations}

The literature also contains studies reporting negative results or with little consistency in the use of brassicas in biofumigation (LU et al., 2010; SMOLIŃSKA \& KOWALCZYK, 2014; KRASNOW \& HAUSBECK, 2015; MAZZOLA et al., 2017; DUTTA et al., 2019). The factors associated with these variations include the brassica species, 
method and management used in biofumigation, the sensitivity of the target species, the phase of the target species cycle, and the influence of chemical, physical, and biological factors in the soil (KIRKEGAARD \& MATTHIESSEN, 2004; FAN et al., 2008; KIRKEGAARD, 2009; CLARKSON et al., 2015; LADHALAKSHMI et al., 2015; MAWAR \& LODHA, 2015; KUMAR et al., 2018; CAMPANELLA et al., 2020). Thus, the methodology and products must be adjusted according to different situations and objects of control: pathogen, pest, or weed. Hence, specific studies are needed to elucidate the species and products most appropriate to each context and production system (CLARKSON et al., 2015), especially in Brazil, where limited information is currently available. The susceptibility of biofumigant species to target organisms or other pathogens and crop pests that are part of the production system can also be a limitation (DONALD et al., 2010; LU et al., 2010; KRASNOW \& HAUSBECK, 2015).

Additionally, most studies on biofumigation have been conducted in laboratory or greenhouse environments (Tables 1 to 6) (DUTTA et al., 2019; MORRIS et al., 2020). Despite the importance of studies performed under controlled conditions to better understand the phenomena involved, studies under field conditions are also essential (DUTTA et al., 2019). Only results from these studies can provide subsidies to improve and implement the technique in commercial crops.

Additionally, theinfluence of biofumigation on beneficial microorganisms present in the soil should also be highlighted, since it is not a selective technique. It can change the soil microbial community, and some authors believe it affects beneficial invertebrates present in the soil (HANSCHEN \& WINKELMANN, 2020). Studies showing the effects of this technique on the effectiveness of associated strategies, such as the use of biocontrol agents, are also necessary (HENDERSON et al., 2009). WANG et al (2014b) reported that the combination of biofumigation with Brassica spp. residues and the antagonist Bacillus amyloliquefaciens increased the bacterial diversity of the soil and influenced certain microbial populations, both positively and negatively. The increased bacterial diversity may have played a significant role in the suppression of Phytophthora capsici in pepper (Capsicum annuum). Nevertheless, the authors suggested that further studies should be conducted before recommending this integrated approach.

\section{Potential use of non-brassica plants and agricultural} residues in biofumigation

In addition to plants of the Brassicaceae family, other species and residues can be investigated and explored for use in biofumigation (ARNAULT et al., 2013; CURTO et al., 2016; GAMLIEL \& BRUGGEN, 2016; WEI et al., 2016). The effects of these materials are related to the production of volatile biotoxic compounds by increasing the microbial activity in the soil and changing its structure (GAMLIEL \& BRUGGEN, 2016). Some species of the genus Allium exert biocidal activity and are recommended for use in biofumigation (ARNAULT et al., 2013) such as, lavender (Lavandula sp.) (WEI et al., 2016), neem (Azadirachta indica) (BARROS et al., 2014), medicinal plants such as citronella (Cymbopogon nardus) and wormseed (Dysphania ambrosioides) (SILVA et al., 2020), and papaya seeds (Carica papaya L.) (NEVES et al., 2008).

The use of organic fertilizers, manure, residues, and nitrogen-rich compounds can also be considered in soil biofumigation due to the release of allelochemicals (MEGHVANSI \& VARMA, 2015; ZEIST et al., 2019). Some examples of residues with promising results are castor bean cake and poultry litter or chicken manure, with or without soil solarization. In this case, it may be classified as soil biosolarization (ROS et al., 2008; VILLALOBOS et al., 2013; ROS et al., 2016).

\section{CONCLUSION}

Biofumigation with plant residues from the family Brassicaceae can be an important strategy in the integrated management of soil organisms that are harmful to crops. Positive results have been reported when the methodologies are correctly used. In biofumigation, brassicas are the most commonly used plants for accumulating GSLs, which release ITCs after enzymatic hydrolysis, with strong biocidal action. However, other plant species (non-brassicas) and organic residues already used in agriculture have potential for use in this way; however, further studies are needed to validate and optimize their use in agriculture.

Biofumigation controls harmful agents by releasing volatile biocidal compounds, with some indirect benefits related to the supply of organic matter to the soil. Therefore, this technique represents a comprehensive management system involving chemical, physical, and biological soil changes, with multiple effects on phytopathogenic agents, pests, and weed species, the soil environment, and plants of economic interest. This technique may be of particular interest for organic production systems and can be integrated with other alternative strategies, such as soil solarization, with projections of improved effects. 
However, biofumigation is not a selective practice. Studies investigating the effects of biofumigation on the beneficial soil microbiota, and on the interaction between biofumigation and biological control with microorganisms remain inconclusive.

Owing to the multiplicity of factors involved, such as biofumigant species, amount of biomass, form of use, physical characteristics of the soil and the target organisms, many studies are required, especially under tropical conditions. There is also a need to fill knowledge gaps and understand the processes and mechanisms involved, the specifics of each material used, and the effects on different groups of phytopathogens, pests, and on the soil microbiota and microfauna. Finally, the cultural component should also be considered, with reluctance to replace chemical fumigants with biofumigation, which is a less harmful option to the environment.

\section{ACKNOWLEDGEMENTS}

To the Conselho Nacional de Desenvolvimento Científico e Tecnológico, Brazil (CNPq) by scholarship (140566/2017-1). This work was financed in part by the Coordenação de Aperfeiçoamento de Pessoal de Nível Superior (CAPES), Brazil - Finance code 001.

\section{DECLARATION OF CONFLICTS OF INTERESTS}

The authors declare no conflict of interest. The founding sponsors had no role in the design of the study; in the collection, analyses, or interpretation of data; in the writing of the manuscript, and in the decision to publish the results.

\section{AUTHORS' CONTRIBUTIONS}

The authors contributed equally to the manuscript.

\section{REFERENCES}

AGROFIT. Sistema de Agrotóxicos Fitossanitários do Ministério da Agricultura. 2020. Available from: $<$ http://agrofit.agricultura.gov. br/agrofit_cons/principal_agrofit_cons>. Accessed: Apr. 15, 2020.

ARNAULT, I. et al. Use of Alliaceae residues to control soil-borne pathogens. Industrial crops and products, v.49, p.265-272, 2013. Available from: <https://doi.org/10.1016/j.indcrop.2013.05.007>. Accessed: Nov. 12, 2019. doi: 10.1016/j.indcrop.2013.05.007.

AYDINLI, G.; MENNAN, S. Biofumigation studies by using Raphanus sativus and Eruca sativa as a winter cycle crops to control root-knot nematodes. Brazilian Archives of Biology and Technology, v.61, 2018. Available from: <https://doi. org/10.1590/1678-4324-2018180249>. Accessed: Apr. 17, 2020. doi: $10.1590 / 1678-4324-2018180249$.

BAKER, L. W. et al. Ambient air concentrations of pesticides in California. Environmental Science \& Technology, v.30, p.365-
1368, 1996. Available from <https://doi.org/10.1021/es9506081 >. Accessed: Nov. 20, 2019. doi: 10.1021/es9506081.

BANDYOPADHYAY, S.; KHALKO, S. Biofumigation - An eco-friendly approach for managing bacterial wilt and soft rot disease of ginger. Indian Phytopathology, v.69, n.1, p.53-56, 2016. Available from: <https://bit.ly/2RV1gpUbiofumigation>. Accessed: Apr. 17, 2020.

BARRAU, C. et al. Brassica carinata for control of Phytophthora spp. in strawberry field crops. Revista de Ciências Agrárias, v.32, n.2, p.135-138, 2009. Available from: <http://www.scielo.mec.pt/ pdf/rca/v32n2/v32n2a13.pdf >. Accessed: Mar. 18, 2020.

BARROS, A. F. et al. Exposure time of second stage juveniles to volatiles emitted by neem and mustard macerates and biofumigation against Meloidogyne incognita. Nematropica, v.44, n.2, p.190-199, 2014. Available from: <https://journals.flvc.org/ nematropica/article/view/84284>. Accessed: Mar. 15, 2019.

BHERING, A. S. et al. Soil management in a mountain agroecosystem and clubroot disease. Plant Pathology, v.69, n.2, 302-309, 2020. Available from: <https://doi.org/10.1111/ ppa.13123>. Accessed: Jun. 30, 2020. doi: 10.1111/ppa.13123.

BRUGGEN, A. H. C. et al. Plant disease management in organic farming systems. Pest Management Science, v. 72, n. 1, p. 3044, 2016. Available from: <https://doi.org/10.1002/ps.4145>. Accessed: Jun. 28, 2020. doi: 10.1002/ps.4145.

BRUGGEN, A. H. C.; FINCKH, M. R. Plant diseases and management approaches in organic farming systems. Annual Review of Phytopathology, v.54, p.25-54, 2016. Available from: <https://www.annualreviews.org/doi/10.1146/annurevphyto-080615-100123>. Accessed: Dec. 20, 2019. doi: 10.1146/ annurev-phyto-080615-100123.

BURKI, F. et al. Evolution of Rhizaria: new insights from phylogenomic analysis of uncultivated protists. BMC Evolutionary Biology, v.10, p.377, 2010. Available from: $<\mathrm{https} / / /$ doi.org/10.1186/1471-2148-10-377>. Accessed: Jun. 30, 2020. doi: $10.1186 / 1471-2148-10-377$.

CAMPANELLA, V. et al. Management of common root rot and Fusarium foot rot of wheat using Brassica carinata break crop green manure. Crop Protection, v.130, 2020. Available from: $<$ https://doi.org/10.1016/j.cropro.2019.105073>. Accessed: Apr. 15, 2020. doi: 10.1016/j.cropro.2019.105073.

CAUWER, B. et al. Impact of Brassica juncea biofumigation on viability of propagules of pernicious weed species. Weed Research, v.59, n.3, p.209-221, 2019. Available from: $<$ https://doi. org/10.1111/wre.12358>. Accessed: Apr. 27, 2020. doi: 10.1111/ wre. 12358 .

CHEAH, L. H. et al. Brassica crops and a Streptomyces sp. as potential biocontrol for clubroot of brassicas. New Zealand Plant Protection, v.54, p.80-83, 2001. Available from: <https://doi. org/10.30843/nzpp.2001.54.3779>. Accessed: Dec. 12, 2019. doi: 10.30843/nzpp.2001.54.3779.

CHEAH, L. H. et al. Clubroot control using Brassica break crops. Acta Hort, v.706, p.329-332, 2006. Available from: <https://doi. org/10.17660/ActaHortic.2006.706.39>. Accessed: Nov. 27, 2020. doi: 10.17660/ActaHortic.2006.706.39. 
CLARKSON, J. et al. Biofumigation for the control of soil-borne diseases. EPI-AGRI. Soil-borne diseases. 2015. Available from $<$ https://ec.europa.eu/eip/agriculture/sites/agri-eip/files/9_eip sbd_mp_biofumigation_final_0.pdf $>$. Accessed: Sep. 16, 2019.

CURTO, G. et al. Biofumigant effect of new defatted seed meals against the southern root-knot nematode, Meloidogyne incognita. Annals of applied biology, v.169, n.1, 17-26, 2016. Available from: < https://doi.org/10.1111/aab.12275>. Accessed: Apr. 19, 2020. doi: 10.1111/aab.12275.

DANEEL, M. et al. The host status of Brassicaceae to Meloidogyne and their effects as cover and biofumigant crops on root-knot nematode populations associated with potato and tomato under South African field conditions. Crop protection, v.110, p.198-206, 2018. Available from: $<$ https://doi.org/10.1016/j. cropro.2017.09.001>. Accessed: May, 02, 2020. doi: 10.1016/j. cropro.2017.09.001.

DHINGRA, O. D. et al. Potential of soil fumigation with mustard essential oil to substitute biofumigation by cruciferous plant species. Tropical plant pathology, v.38, n.4, p.337342, 2013. Available from: <https://doi.org/10.1590/S198256762013005000014>. Accessed: Mar. 27, 2020. doi: 10.1590/ S1982-56762013005000014

DIXON, G. R.; TILSTON E. L. Soil-borne pathogens and their interactions with the soil environment. In: DIXON, G. R.; TILSTON, E. L. Soil Microbiology and Sustainable Crop Production. Dordrecht, Netherlands: Springer, 2010. Cap. 6, p. 197-271.

DONALD, D. et al. Managing Soilborne Diseases in Vegetables: Rotation with green manure and biofumigant crops shows disease control \& yield benefits. Victoria: Department of Primary Industries, 2010. Available from: <https://ausveg.com.au/app/data/ technical-insights/docs/VG07125_Soilborne_Diseases_brochure. pdf>. Accessed: Nov. 27, 2019.

DUTTA, T. K. et al. Plant-parasitic nematode management via biofumigation using brassica and non-brassica plants: Current status and future prospects. Current Plant Biology, v.17, p.17-32, 2019. Available from: <https://doi.org/10.1016/j.cpb.2019.02.001> Accessed: Apr. 15, 2020. doi: 10.1016/j.cpb.2019.02.001

EPSTEIN, L. Fifty Years Since Silent Spring. Annual Review of Phytopathology, v.52, p.377-402, 2014. Available from: <https:/ doi.org/10.1146/annurev-phyto-102313-045900>. Accessed: Sep. 20, 2019. doi: 10.1146/annurev-phyto-102313-045900.

FAN, C. M. et al. Potential biofumigation effects of Brassica oleracea var. caulorapa on growth of fungi. Journal of Phytopathology, v.156, n.6, p.321-325, 2008. Available from: $<$ https://doi.org/10.1111/j.1439-0434.2007.01343.x>. Accessed: Apr. 15, 2020. doi: 10.1111/j.1439-0434.2007.01343.x.

FURLAN, L. et al. The efficacy of biofumigant meals and plants to control wireworm populations. Industrial crops and products, v.31, n.2, p.245-254, 2010. Available from: $<$ https://doi. org/10.1016/j.indcrop.2009.10.012>. Accessed: Apr. 23, 2020. doi: 10.1016/j.indcrop.2009.10.012.

GAMLIEL, A.; BRUGGEN, A. H. C. Maintaining soil health for crop production in organic greenhouses. Scientia Horticulturae, v.208, p.120-130, 2016. Available from <https://doi.org/10.1016/j. scienta.2015.12.030>. Accessed: Sep. 15, 2019. doi: 10.1016/j. scienta.2015.12.030.
GAMLIEL, A.; KATAN, J. Control of plant disease through soil solarization. In: WALTERS, D. Disease Control in Crops: Biological and Environmentally Friendly Approaches. Oxford: Wiley-Blackwell, 2009. Cap. 10, p. 196-220.

GIMSING, A. L.; KIRKEGAARD, J. A. Glucosinolates and biofumigation: fate of glucosinolates and their hydrolysis products in soil. Phytochemistry Reviews, v.8, n.1, p.299-310, 2009. Available from <https://doi.org/10.1007/s11101-008-9105-5>. Accessed: Dec. 15, 2019. doi: 10.1007/s11101-008-9105-5.

GOUWS R.; WEHNER F.C. Biofumigation as alternative control measure for common scab on seed potatoes in South Africa. Agroindustria, v.3, p.309-312, 2004.

GUREL, F. B. et al. Biofumigation: Opportunities and challenges for control of soilborne diseases in nursery production. Plant Health Progress, v. 19, n. 4, p. 332-337, 2018. Available from: $<$ https://doi.org/10.1094/PHP-08-18-0049-RV>. Accessed: May, 15, 2020. doi: 10.1094/PHP-08-18-0049-RV.

HANSCHEN, F. S.; WINKELMANN, T. Biofumigation for fighting replant disease- A Review. Agronomy, v.10, n.3, 2020. Available from: <https://doi.org/10.3390/agronomy10030425>. Accessed: Apr. 15, 2020. doi: 10.3390/agronomy10030425.

HENDERSON, D. R. et al. Mustard biofumigation disrupts biological control by Steinernema spp. nematodes in the soil. Biological control, v.48, n.3, p.316-322, 2009. Available from: $<$ https://doi.org/10.1016/j.biocontrol.2008.12.004>. Accessed: Apr. 15, 2020. doi: 10.1016/j.biocontrol.2008.12.004.

IRIARTE, L. E. Efecto de la biofumigación con repollo sobre el control de Fusarium oxysporum en suelo. RIA. Revista de Investigaciones Agropecuarias, v.37, n.3, p.231-237, 2011. Available from: <https://www.redalyc.org/pdf/864/86421245007. pdf $>$. Accessed: Apr. 15, 2020.

JIN, X. et al. Rotations with Indian mustard and wild rocket suppressed cucumber Fusarium wilt disease and changed rhizosphere bacterial communities. Microorganisms, v.7, n.2, p.57, 2019. Available from: <http://dx.doi.org/10.3390/ microorganisms7020057>. Accessed: Mar. 19, 2020. doi: 10.3390/ microorganisms 7020057 .

KARAVINA, C.; MANDUMBU, R. Biofumigation for crop protection: potential for adoption in Zimbabwe. Journal of Animal \& Plant Sciences, v.14, n.3, 1996-2005, 2012. Available from: $<$ http://www.m.elewa.org/JAPS/2012/14.3/3.pdf $>$. Accessed: Apr. 18,2020

KIRKEGAARD, J.A. et al. Biofumigation - using Brassica species to control pests and diseases in horticulture and agriculture. In: Wratten, N.: MAILER, R. J. Proceedings of the $9^{\text {th }}$ Australian Research Assembly on Brassicas. Wagga Wagga, The Assembly, 1993. p.77-82.

KIRKEGAARD, J. Biofumigation for plant disease control - from the fundamentals to the farming system. In: WALTERS, D. Disease Control in Crops: Biological and Environmentally Friendly Approaches. Oxford: Wiley-Blackwell, 2009. Cap. 9, p. 172-195.

KIRKEGAARD， J.; MATTHIESSEN， J. Developing and refining the biofumigation concept. Agroindustria, v.3, p.233239, 2004. Available from <http://hdl.handle.net/102.100.100/181 385? index $=1>$. Accessed: Nov. 17, 2019. 
KRASNOW, C. S.; HAUSBECK, M. K. Pathogenicity of Phytophthora capsici to Brassica vegetable crops and biofumigation cover crops (Brassica spp.). Plant disease, v.99, n.12, p.1721-1726, 2015. Available from: < https://doi.org/10.1094/ PDIS-03-15-0271-RE>. Accessed: Mar. 18, 2020. doi: 10.1094/ PDIS-03-15-0271-RE.

KUMAR, G. N. K. et al. Disease management by Biofumigation in organic farming system. Journal of Pharmacognosy and Phytochemistry, v.7, n.4, p.676-679, 2018. Available from: $<$ http://www.phytojournal.com/archives/2018/vol7issue4/ PartK/7-3-654-578.pdf $>$. Accessed: Sep. 8, 2019.

LADHALAKSHMI, D. et al. Biofumigation in crop disease management. In: GANESAN, S. et al. Sustainable Crop Disease Management using Natural Products. Boston: $C A B$ International, 2015. Cap.19, p.389-402.

LARREGLA, S. et al. Biodisinfestation with organic amendments for soil fatigue and soil-Borne pathogens control in protected pepper crops. In: MEGHVANSI M.; VARMA A. Organic Amendments and Soil Suppressiveness in Plant Disease Management. Cham: Springer, 2015. Cap.21, p.437-456.

LAZZERI, L. et al. Biocidal plant dried pellets for biofumigation. Industrial Crops and Products, v.20, p.59-65, 2004. Available from: <https://doi.org/10.1016/j.indcrop.2003.12.018>. Accessed: Sep. 8, 2019. doi: 10.1016/j.indcrop.2003.12.018.

LAZZERI, L. et al. Bio-based products from Brassica carinata A Braun oils and defatted meals by a second generation biorefinery approach. Proc. 19 ${ }^{\text {th }}$ European Biomass Conference. Berlin, Germany, 6-10, p.1080-1092. 2011. Available from: <http://www etaflorence.it/proceedings/?detail=7244>. Accessed: Dec. 18, 2019. doi: 10.5071/19thEUBCE2011-OA12.5.

LAZZERI, L. et al. The Brassicaceae biofumigation system for plant cultivation and defence. An Italian twenty-year experience of study and application. Acta Hortic, v.1005, p.375-382, 2013. Available from: <https://doi.org/10.17660/ ActaHortic.2013.1005.44> Accessed: Sep. 8, 2019. doi: 10.17660/ ActaHortic.2013.1005.44.

LEFEBVRE, M. Seed dormancy and seed morphology related to weed susceptibility to biofumigation. Weed Science, v. 66, n 2, p. 199-214, 2018. Available from: <https://doi.org/10.1017/ wsc.2017.66> Accessed: Mar. 27, 2020. doi: 10.1017/wsc.2017.66.

LEITE, I. C. H.; LOPES, U. P. Controle químico de patógenos radiculares. In: LOPES, U. P.; MICHEREFF, S. J. (eds). Desafios do Manejo de Doenças Radiculares Causadas por Fungos. Recife: EDUFRPE, 2018. Cap. 11, p. 179-192.

LOBO JÚNIOR, M. L. et al. Panorama da pesquisa com patógenos radiculares no Brasil. In: LOPES, U. P.; MICHEREFF, S. J. (eds). Desafios do Manejo de Doenças Radiculares Causadas por Fungos. Recife: EDUFRPE, 2018. Cap.2, p.17-34.

LORD, J. S., et al. Biofumigation for control of pale potato cyst nematodes: activity of brassica leaf extracts and green manures on Globodera pallida in vitro and in soil. Journal of Agricultural and Food Chemistry, v.59, p.7882-7890, 2011. Available from: $<$ https://doi.org/10.1021/jf200925k> Accessed: Jun. 12, 2019. doi: $10.1021 / \mathrm{jf} 200925 \mathrm{k}$.

LU, P. et al. Biofumigation with Brassica plants and its effect on the inoculum potential of Fusarium yellows of Brassica crops.
European Journal of Plant Pathology, v.126, n.3, p.387-402, 2010. Available from: <https://doi.org/10.1007/s10658-0099543-y>. Accessed: May, 1, 2020. doi: 10.1007/s10658-0099543-y.

MARSCHNER, P.; RENGEL, Z. The effects of plant breeding on soil microbes. In: DIXON, G. R.; TILSTON, E. L. Soil Microbiology and Sustainable Crop Production. Dordrecht, Netherlands: Springer, 2010. Cap. 8, p. 297-315.

MATTHIESSEN, J. N.; KIRKEGAARD, J. A. Biofumigation and enhanced biodegradation: opportunity and challenge in soilborne pest and disease management. Critical Reviews in Plant Sciences, v.25, p.235-65, 2006. Available from: $<$ https://doi. org/10.1080/07352680600611543> Accessed: Jun. 12, 2019. doi: $10.1080 / 07352680600611543$.

MAWAR, R.; LODHA, S. Suppression of soilborne plant pathogens by cruciferous residues. In: MEGHVANSI M.; VARMA A. (eds). Organic Amendments and Soil Suppressiveness in Plant Disease Management. Cham: Springer, 2015. Cap.20, p.413-433.

MAZZOLA, M. et al. Incorporation of Brassica seed meal soil amendment and wheat cultivation for control of Macrophomina phaseolina in strawberry. European journal of plant pathology, v.149, n.1, p.57-71, 2017. Available from: <https://doi.org/10.1007/ s10658-017-1166-0>. Accessed: Apr. 28, 2020. doi: 10.1007/ s10658-017-1166-0.

MEGHVANSI, M. K., VARMA, A. (Eds.). Organic amendments and soil suppressiveness in plant disease management. Dordrecht: Springer, 2015.

MICHEL, V.V. Ten years of biofumigation research in Switzerland. Aspects of Applied Biology, v.126, p.33-42, 2014. Available from: <http://link.ira.agroscope.ch/en-US/publication/34214>. Accessed: Sep. 8, 2019.

MORALES-RODRÍGUEZ, C. et al. Efficacy of biofumigation with Brassica carinata commercial pellets (BioFence) to control vegetative and reproductive structures of Phytophthora cinnamomi. Plant Disease, v.100, n.2, p.324-330, 2016. Available from: $<$ https://doi.org/10.1094/PDIS-03-15-0245-RE >. Accessed: Mar. 16, 2020. doi: 10.1094/PDIS-03-15-0245-RE.

MORALES-RODRÍGUEZ, C. et al. Application of Trichoderma spp. complex and biofumigation to control damping-off of Pinus radiata D. Don caused by Fusarium circinatum Nirenberg and O'Donnell. Forests, v.9, n.7, p.421, 2018. Available from: $<$ https://doi.org/10.3390/f9070421>. Accessed: Mar. 16, 2020. doi: $10.3390 / \mathrm{f} 9070421$.

MORRIS, E. K. et al. Effective methods of biofumigation: a metaanalysis. Plant and Soil, v.446, p.379-392, 2020. Available from: $<$ https://doi.org/10.1007/s11104-019-04352-y>. Accessed: Apr. 15, 2020. doi: 10.1007/s11104-019-04352-y.

MOTISI, N. et al. Epidemiological analysis of the effects of biofumigation for biological control of root rot in sugar beet. Plant Pathology, v.62, n.1, p.69-78, 2013. Available from: <https://doi. org/10.1111/j.1365-3059.2012.02618.x>. Accessed: Apr. 24, 2020. doi: $10.1111 / \mathrm{j} .1365-3059.2012 .02618 . x$.

NEUBAUER, C. et al. Biofumigation potential of Brassicaceae cultivars to Verticillium dahliae. European Journal of Plant 
Pathology, v.140, n.2, p.341-352, 2014. Available from: <https:// doi.org/10.1007/s10658-014-0467-9>. Accessed: Mar. 12, 2020. doi: 10.1007/s10658-014-0467-9.

NEVES, W. S. et al. The use of papaya-seed and solarization for the control of Meloidogyne javanica and Meloidogyne incognita. Nematologia Brasileira, v.32, n.4, p.253-259, 2008. Available from: $\quad<$ https://nematologia.com.br/files/revnb/32_4.pdfs. Accessed: Jun. 28, 2020

NGALA, B. M. et al. Biofumigation with Brassica juncea, Raphanus sativus and Eruca sativa for the management of field populations of the potato cyst nematode Globodera pallida. Pest Management Science, v.71, n.5, p.759-769, 2015. Available from: $<$ https://doi.org/ 10.1002/ps.3849>. Accessed: Mar. 15, 2020. doi: $10.1002 /$ ps.3849.

NICOLA, G.R. et al. A new biobased liquid formulation with biofumigant and fertilizing properties for drip irrigation distribution. Industrial Crops and Products, v.42, p.113-118, 2013. Available from: <https://doi.org/10.1016/j.indcrop.2012.05.018>. Accessed: Jul. 15, 2019. doi: 10.1016/j.indcrop.2012.05.018.

NTALLI, N.;CABONI,P.Areview of isothiocyanates biofumigation activity on plant parasitic nematodes. Phytochemistry Reviews, v. 6, n.5, p.827-834, 2017. Available from: <https://doi.org/10.1007/ s11101-017-9491-7>. Accessed: Apr. 16, 2020. doi: 10.1007/ s11101-017-9491-7.

OJAGHIAN, M. R. et al. In vitro biofumigation of Brassica tissues against potato stem rot caused by Sclerotinia sclerotiorum. The Plant Pathology Journal, v.28, n.2, p.185-190, 2012. Available from: $\quad<\mathrm{http}: / / \mathrm{dx}$.doi.org/10.5423/PPJ-OA-11-2011-0206> Accessed: Mar. 15, 2020. doi: 10.5423/PPJ-OA-11-2011-0206.

OLIVEIRA, R. D. L. et al. Glucosinolate content and nematicidal activity of Brazilian wild mustard tissues against Meloidogyne incognita in tomato. Plant and Soil, v. 341, n. 1-2, p. 155-164, 2011. Available from: $<$ https://doi.org/10.1007/s11104-010-06318>. Accessed: Apr. 20, 2020. doi: 10.1007/s11104-010-0631-8.

PAN, X. et al. Effect of oriental mustard (Brassica juncea) seed meal for control of dollar spot on creeping bentgrass (Agrostis stolonifera) Turf. International Turfgrass Society Research Journal, v.13, n.1, p.166-174, 2017. Available from: $<$ https://doi. org/10.2134/itsrj2016.06.0455>. Accessed: Apr. 17, 2020. doi: 10.2134 /itsrj2016.06.0455

PERNIOLA, O. S et al. Biofumigación con Brassicáceas: actividad supresora sobre Fusarium graminearum. Revista de la Facultad de Agronomía, v.111, n.1, p.48-53, 2012. Available from: <http:// revista.agro.unlp.edu.ar/index.php/revagro/article/view/71>. Accessed: Apr. 16, 2020.

PERNIOLA, O. S. et al. Control biológico de Fusarium graminearum: utilización de Trichoderma spp. y biofumigación con parte aérea de Brassica juncea. Revista de la Facultad de Ciencias Agrarias, v.46, n.2, p.45-56, 2014. Available from: <https:// ri.conicet.gov.ar/handle/11336/33015>. Accessed: Apr. 16, 2020.

PERNIOLA, O. S. et al. Biofumigación in vitro con Brassica juncea y Sinapis alba. Inhibición de la germinación y del crecimiento de plántulas de malezas. Revista de la Facultad de Agronomía, v.115, n.1, p.91-98, 2016. Available from: <http:// revista.agro.unlp.edu.ar/index.php/revagro/article/view/290>. Accessed: Apr. 18, 2020.
PERNIOLA, O. S. et al. Biofumigación con Brassica juncea: efecto sobre la flora arvense. Revista de la Facultad de Agronomía, v.118, n.1, p.25-35, 2019. Available from: <https://revistas.unlp. edu.ar/revagro/article/view/7602>. Accessed: Apr. 18, 2020.

PONTES, N. C. et al. Soil fumigation with mustard essential oil to control bacterial wilt in tomato. European Journal of Plant Pathology, v.155, p.435-444. 2019. Available from: <https://doi. org/10.1007/s10658-019-01777-0>. Accessed: Apr. 20, 2020. doi: $10.1007 / \mathrm{s} 10658-019-01777-0$

PRASAD, P. et al. Biofumigation: Success and Prospects in Soilborne Plant Disease Management. International Journal of Applied And Pure Science and Agriculture, v.1, n.6, p.47-59, 2015. Available from <https://ijapsa.com/published-papers/volume-1/ issue-6/biofumigation-success-and-prospects-in-soilborne-plantdisease-management.pdf $>$. Accessed: Sep. 8, 2019.

PRASAD, P. et al. Investigating disease controlling ability of Brassica volatiles and their compatibility with Trichoderma harzianum. The National Academy of Sciences, 2016. Available from: <https://doi.org/10.1007/s40011-016-0829-5>. Accessed: Apr. 16, 2020. doi: 10.1007/s40011-016-0829-5.

RAHMAN, M. et al. Brassicaceae mustards: Traditional and agronomic uses in Australia and New Zealand. Molecules, v.23, n.1, 2018. Available from: <https://www.ncbi.nlm.nih.gov/ pubmed/29361740>. Accessed: Apr. 15, 2020. doi: doi:10.3390/ molecules 23010231 .

RELEVANTE, C. A.; CUMAGUN, C. J. R. Control of Fusarium wilt in bittergourd and bottlegourd by biofumigation using mustard var. Monteverde. Archives of Phytopathology and Plant Protection, v.46, n.6, p.747-753, 2013. Available from: <https:// doi.org/10.1080/03235408.2012.751285>. Accessed: Apr. 26, 2020. doi: $10.1080 / 03235408.2012 .751285$.

RÍOS, P. et al. Brassica-based seedmeal biofumigation to control Phytophthora cinnamomi in the Spanish "dehesa" oak trees. Phytopathologia Mediterranea, v.56, n.3, p.392-399, 2017. Available from: <https://doi.org/10.14601/Phytopathol Mediterr-20771>. Accessed: Apr. 22, 2020. doi: 10.14601/ Phytopathol_Mediterr-20771.

RONCATO, S. C. et al. Control of Meloidogyne incognita in tomato by crambe extract using different application forms. Summa Phytopathologica, v.44, n.3, p.261-266, 2018. Available from: <https://doi.org/10.1590/0100-5405/179533>. Accessed: May, 7, 2020. doi: 10.1590/0100-5405/179533>.

ROS, M. et al. Effects of biosolarization as methyl bromide alternative for Meloidogyne incognita control on quality of soil under pepper. Biology and Fertility of Soils, v.45, p.37-44, 2008. Available from: $<\mathrm{https}: / /$ link.springer.com/article/10.1007/s00374-008-0307-1>. Accessed: Sep. 8, 2019. doi: 10.1007/s00374-008-0307-1.

ROS, C. et al. El cultivo de brásicas para biosolarización reduce las poblaciones de Meloidogyne incognita en los invernaderos de pimiento del Sudeste de España. Revista de la Asociación Interprofesional para el Desarrollo Agrario (AIDA), v.112, n.2, p.109-126, 2016. Available from: <http://dx.doi.org/10.12706/ itea.2016.008>. Accessed: Mar. 18, 2020. doi: 10.12706/ itea.2016.008.

ROSA, E. A. S. et al. GSLs in crop plants. Horticultural Reviews, v.19, p.99-215, 1997. Available from: <https://www.wiley.com/en- 
us/Horticultural+Reviews\%2C+Volume+19-p-9780471165293>. Accessed: Nov. 15, 2019

ROSSKOPF, E. N. et al. Anaerobic Soil Disinfestation and Soilborne Pest Management In: MEGHVANSI M.; VARMA A. (eds). Organic Amendments and Soil Suppressiveness in Plant Disease Management. Cham: Springer, 2015. Cap. 13, p. 277-306.

RUBAYET, M. T. et al. Effect of biofumigation and soil solarization on stem canker and black scurf diseases of potato (Solanum tuberosum L.) caused by Rhizoctonia solani isolate PR2. Advances in Agricultural Science, v.6, n.3, p.33-48, 2018. Available from: <https://aaasjournal.org/submission/index.php/ aaas/article/view/80>. Accessed: Apr. 19, 2020.

SCHWELM, A. et al. The Plasmodiophora brassicae genome reveals insights in its life cycle and ancestry of chitin synthases. Scientific Reports, v.5, p.1-12, 2015. Available from: $<$ https://doi. org/10.1038/srep11153>. Accessed: Jun. 30, 2020. doi: 10.1038/ srep11153.

SERRANO-PÉREZ, P. et al. Efficacy of Brassica carinata pellets to inhibit mycelial growth and chlamydospores germination of Phytophthora nicotianae at different temperature regimes. Scientia horticulturae, v.216, p.126-133, 2017. Available from: <https:// doi.org/10.1016/j.scienta.2017.01.002>. Accessed: Nov. 18, 2019. doi: 10.1016/j.scienta.2017.01.002.

SHAAYA, E.; KOSTYUKOVSKY, M. The potential of biofumigants as alternatives to methyl bromide for the control of pest infestation in grain and dry food products. In: $\mathbf{1 0}^{\text {th }}$ International Working Conference on Stored Product Protection. Lisbon: Portugal, 2010. p.433- 437.

SILVA, M. F. et al. Medicinal plant volatiles applied against the root-knot nematode Meloidogyne incognita. Crop Protection, v.130, 2020. Available from: <https://doi.org/10.1016/j. cropro.2019.105057>. Accessed: Apr. 28, 2020. doi: 10.1016/j. cropro.2019.105057

SMOLIŃSKA, U.; KOWALCZYK, W. The impact of the Brassicaceae plant materials added to the soil on the population of Fusarium solani (Mart.) Sacc. and Fusarium oxysporum Schlecht. Journal of Horticultural Research, v.22, n.1, p.123-129, 2014 Available from: <https://doi.org/10.2478/johr-2014-0015>. Accessed: Apr. 25, 2020. doi: 10.2478/johr-2014-0015.

TRIUMPH ITALIA. Catalogo. 2015. Available from: <http:// www.ortobiodomestico.com/catalogo/files/assets/basic-html/ index.html\#1>. Accessed: Jun. 28, 2020.

TSROR, L. et al. Biofumigation for the control of soilborne diseases. Acta horticulturae, v.747, 389-394, 2007. Available from: $\quad<$ https://doi.org/10.17660/ActaHortic.2007.747.48>. Accessed: Nov. 17, 2019. doi: 10.17660/ActaHortic.2007.747.48.

UGRENOVIĆ, V. et al. Effect of Brassicaceae as cover crops. Selekcija I Semenarstvo, v.25, n.2, p.1-8, 2019. Available from: $<$ http://dx.doi.org/10.5937/SelSem1902001U>. Accessed: Apr. 15, 2020. doi: doi:10.3390/molecules23010231.

VILlalobos, J. A. M.; et al. Producción de chile (Capsicum annuum L.) a campo abierto con biofumigación del suelo. Durango: INIFAP, 2013. Available from: <http://biblioteca. inifap.gob.mx:8080/jspui/handle/123456789/4097>. Accessed: Sep. 02, 2019.

WANG, K. H et al. Effects of cover cropping, solarization, and soil fumigation on nematode communities. Plant and Soil, v.286, n.1-2, p.229-243, 2006. Available from: <https://doi.org/10.1007/ s11104-006-9040-4>. Accessed: Mar. 21, 2020. doi: 10.1007/ s11104-006-9040-4.

WANG, Q. et al. Effect of biofumigation and chemical fumigation on soil microbial community structure and control of pepper Phytophthora blight. World Journal of Microbiology and Biotechnology, v.30, n.2, p.507-518, 2014a. Available from: $<$ https://doi.org/10.1007/s11274-013-1462-6>. Accessed: Apr. 22, 2020. doi: 10.1007/s11274-013-1462-6.

WANG, Q. et al. Integration of biofumigation with antagonistic microorganism can control Phytophthora blight of pepper plants by regulating soil bacterial community structure. European Journal of Soil Biology, v.61, p.58-67, 2014b. Available from: $<$ https://doi. org/10.1016/j.ejsobi.2013.12.004>. Accessed: Apr. 22, 2020. doi: 10.1016/j.ejsobi.2013.12.004

WARMINGTON, R.; CLARKSON, J. P. Volatiles from biofumigant plants have a direct effect on carpogenic germination of sclerotia and mycelial growth of Sclerotinia sclerotiorum. Plant and Soil, v.401, n.1-2, p. 213-229, 2016. Available from: $<$ https:// doi.org/10.1007/s11104-015-2742-8>. Accessed: Apr. 18, 2020. doi: $10.1007 / \mathrm{s} 11104-015-2742-8$.

WEI, F. et al. Effects of individual and combined use of biofumigation-derived products on the viability of Verticillium dahliae microsclerotia in soil. Crop Protection, v.79, p.170-176, 2016. Available from: <https://doi.org/10.1016/j.cropro.2015.09.008>. Accessed: Dec. 18, 2019. doi: 10.1016/j.cropro.2015.09.008.

ZEIST, A.R. et al. Combination of solarization, biofumigation and grafting techniques for the management of bacterial wilt in tomato. Horticultura Brasileira, v.37, p.260-265, 2019. Available from: $<$ http://dx.doi.org/10.1590/S0102-053620190302>. Accessed: Apr. 18. 2020. doi: 10.1590/S0102-053620190302. 